\title{
Wiedza i poglądy nauczycieli religii na tematy związane z ochroną i kształtowaniem środowiska naturalnego
}

\begin{abstract}
Wstęp
W wielu środowiskach zainteresowanych ochroną przyrody edukacja ekologiczna jest uważana za jeden z najważniejszych środków prowadzących do przeobrażenia świadomości społeczeństwa w kierunku świadomości „proekologicznej”. Wysoka pozycja edukacji środowiskowej to wynik potencjalnie długotrwałego oddziaływania na ludzi. Zachodzi potrzeba wpisania jej treści do nauczania i wychowania na poziomie elementarnym, średnim i wyższym, także w proces kształcenia dorosłych.

Rozwój ekoteologii w ostatnich latach oraz nauczanie proekologiczne Jana Pawła II jest dobrym fundamentem do tworzenia do tworzenia ścieżek edukacyjnych na lekcjach religii na poziomie od przedszkola do szkoły średniej włącznie.

W celu przygotowania kadr, które w mogą zająć się edukacją ekologiczną na lekcjach religii należy najpierw zbadać wiedzę i poglądy nauczycieli religii na problematykę ochrony środowiska. Stąd istnieje potrzeba prowadzenia tego rodzaju badań.

Na miejsce bada wybrano diecezję łomżyńską. Badaniu ankietowemu poddano 35\% katechetów aktualnie uczących na wszystkich poziomach nauczania. Zachowano zasadę dobrowolności i anonimowości.
\end{abstract}

\section{Miejsce badań}

Obiektem dociekań nad wiedzą i poglądami nauczycieli religii autor uczynił teren diecezji łomżyńskiej, która może stanowić odzwierciedlenie większości diecezji w Polsce, ponieważ jest to diecezja o dużych tradycjach i zróżnicowanym terytorium pod względem geograficznym i kulturowym. 
Diecezja łomżyńska zajmuje obszar $11500 \mathrm{~km}^{2}$ na terenie trzech województw:

- podlaskiego - 95 parafii

- mazowieckiego - 83 parafie

- warmińsko-mazurskiego - 1 parafia

na terenie tym zamieszkuje 579280 osób z czego 571561 osób wyznaje religię rzymsko-katolicką.

W diecezji łomżyńskiej pracuje: 223 - księży uczących w szkole, 43 - siostry zakonne uczące w szkole, 497 - katechetów świeckich.

W roku 2003 w Wyższym Seminarium Duchownym w Łomży studiowało -87 alumnów.

W Łomży działa również Instytut Teologiczny im. bł. ks. dr-a Michała Piaszczyńskiego, gdzie studiuje kilkadziesiąt osób. ${ }^{1}$

\section{Organizacja i przebieg badań}

Badania ankietowe przeprowadzono wśród nauczycieli religii w diecezji łomżyńskiej od listopada $2004 \mathrm{r}$. do kwietnia $2005 \mathrm{r}$. W środowisku rozprowadzono za pośrednictwem Wydziału Wychowania i Nauczania Katolickiego Łomżyńskiej Kurii Diecezjalnej 760 ankiet, z czego przyjęto do analizy 266 , co stanowi $35 \%$ badanej grupy.

Grupa składała się z 192 kobiet (72,18 \%) i 70 mężczyzn (26,31 \%), 4 osoby nie podało swojej płci (1,5\%), we wszystkich przypadkach zachowano zasadę anonimowości i dobrowolności uczestnictwa.

Ankietowani zostali przyporządkowani do pięciu kategorii wiekowych. Najliczniejszą grupą, stanowiącą 51,5\% badanych, były osoby z przedziału 31 - 40 lat. Kolejne dwie grupy osób w wieku $41-50$ lat oraz $26-30$ lat stanowiły $25,94 \%$ i $10,9 \%$. Natomiast w przedziałach wiekowych $51-65$ lat i do 25 lat udział osób był znacznie mniejszy i wynosił 6,39 \% i 1,88\% wszystkich badanych. Ponadto 11 osób $(4,13 \%)$ nie wypełniło rubryki.

Wiek nauczycieli

\begin{tabular}{|l|r|c|}
\hline \multicolumn{1}{|c|}{ Zmienne niezależne } & \multicolumn{2}{|c|}{$\begin{array}{c}\text { Wiek nauczycieli } \\
\text { (N= 266) }\end{array}$} \\
\hline Do 25 lat & 5 & $1,88 \%$ \\
\hline $26-30$ lat & 29 & $10,90 \%$ \\
\hline $31-40$ lat & 137 & $51,50 \%$ \\
\hline $41-50$ lat & 69 & $25,94 \%$ \\
\hline $51-65$ lat & 17 & $6,39 \%$ \\
\hline Brak danych & 11 & $4,13 \%$ \\
\hline
\end{tabular}

1 Dane statystyczne pochodzą z roku 2003. por. Rocznik Diecezji Łomżyńskiej 2003, Łomża 2003, s. $14-16$. 


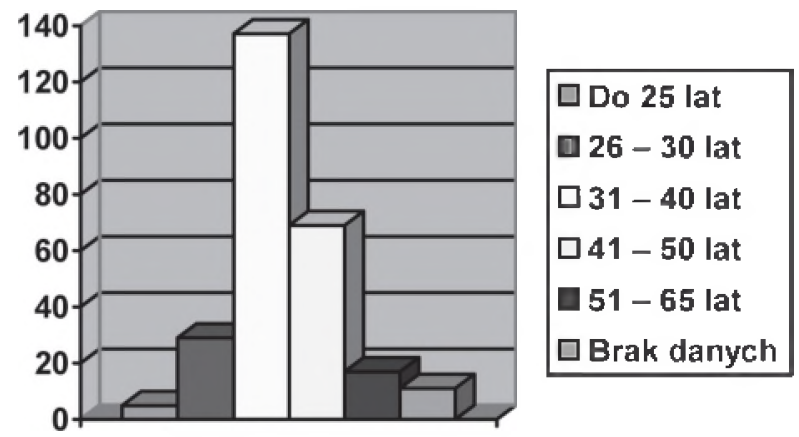

Badane osoby posiadały różny staż pracy w zawodzie nauczyciela. Wszyscy zostali przyporządkowani do czterech kategorii. Najliczniejszą stanowili nauczyciele pracujący w zawodzie $11-20$ lat $(41,73 \%)$. Mniej liczne grupy to nauczyciele pracujący 6 - 10 lat $(24,44 \%)$ oraz do 5 lat $(15,79 \%)$. Najmniej liczną grupę stanowili najbardziej doświadczeni nauczyciele posiadający staż pracy w zawodzie powyżej 21 lat (5,26 \%). Zaskakujący jest tu fakt, że 12,78 \% nie podało swych danych.

\section{Staź pracy}

\begin{tabular}{|l|r|r|}
\hline \multicolumn{1}{|c|}{ Zmienne niezależne } & \multicolumn{2}{c|}{$\begin{array}{c}\text { Staż pracy } \\
\text { (N = 266) }\end{array}$} \\
\hline Do 5 lat & 42 & $15,79 \%$ \\
\hline 6 - 10 lat & 65 & $24,44 \%$ \\
\hline 11 - 20lat & 111 & $41,73 \%$ \\
\hline 21 i więcej & 14 & $5,26 \%$ \\
\hline Brak danych & 34 & $12,78 \%$ \\
\hline
\end{tabular}

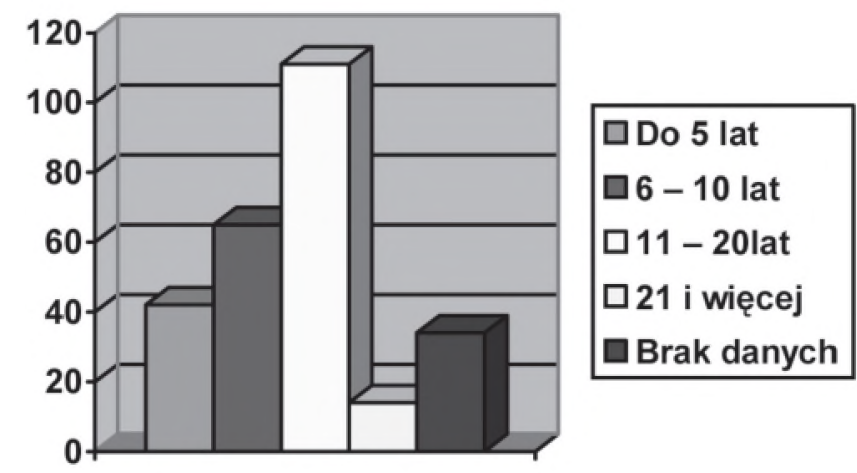


Wśród badanych nauczycieli $65,79 \%$ posiadało stopień nauczyciela mianowanego, 16,54 \% nauczyciela kontraktowego, 12,40 \% nauczyciela dyplomowanego i $3,76 \%$ nauczyciela stażysty. Cztery osoby nie wypełniły podanej rubryki.

Statut zawodowy

\begin{tabular}{|l|r|r|}
\hline \multicolumn{1}{|c|}{ Zmienne niezależne } & \multicolumn{2}{c|}{$\begin{array}{c}\text { Statut zawodowy } \\
(\mathbf{N}=\mathbf{2 6 6})\end{array}$} \\
\hline Nauczyciel stażysta & 10 & $3,76 \%$ \\
\hline Nauczyciel kontraktowy & 44 & $16,54 \%$ \\
\hline Nauczyciel mianowany & 175 & $65,79 \%$ \\
\hline Nauczyciel dyplomowany & 33 & $12,40 \%$ \\
\hline Brak danych & 4 & $1,50 \%$ \\
\hline
\end{tabular}
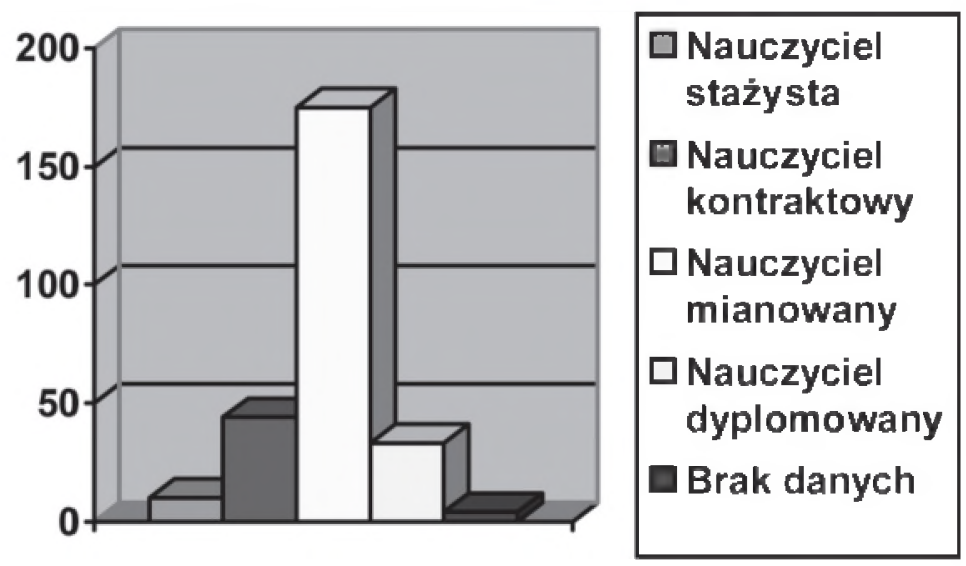

Wśród badanych 33,46\% posiadało wykształcenie wyższe teologiczne (magistrowie teologii) $63,16 \%$. Z tego 47,02 \% dodatkowo ukończyło studia podyplomowe. W badanej grupie wzięli udział księża, którzy stanowili 13,91 \% grupy, z tego 27,02 \% oprócz studiów w Wyższym Seminarium Duchownym ukończyto dodatkowe studia specjalistyczne. Ponadto $10,53 \%$ badanej grupy posiadało wykształcenie wyższe nieteologiczne i ukończone kolegium katechetyczne lub studia podyplomowe $\mathrm{z}$ teologii dające uprawnienia do uczenia religii w szkole. Z badanej grupy 11,27 \% ukończyło kolegium katechetyczne, a 1,13\% posiadało jedynie wykształcenie średnie. 
Tab. 4. Wykształcenie

\begin{tabular}{|c|c|c|}
\hline \multirow{2}{*}{$\begin{array}{l}\text { Zmienne niezależne } \\
\text { Srednie }\end{array}$} & \multicolumn{2}{|c|}{$\begin{array}{l}\text { Wykształcenie nauczycieli } \\
\qquad(\mathrm{N}=266)\end{array}$} \\
\hline & 3 & $1,13 \%$ \\
\hline Ukończone Kolegium katechetyczne & 30 & $11,27 \%$ \\
\hline Wyższe (magister teologii) & 89 & $33,46 \%$ \\
\hline $\begin{array}{l}\text { Wyższe + Kolegium Katechetyczne } \\
\text { lub studia podyplomowe }\end{array}$ & 28 & $10,53 \%$ \\
\hline $\begin{array}{l}\text { Wyższe (magister teologii) + studia } \\
\text { podyplomowe }\end{array}$ & 79 & $29,70 \%$ \\
\hline Ukończone WSD & 27 & $10,15 \%$ \\
\hline $\begin{array}{l}\text { Ukończone WSD + studia specjali- } \\
\text { styczne }\end{array}$ & 10 & $3,76 \%$ \\
\hline
\end{tabular}

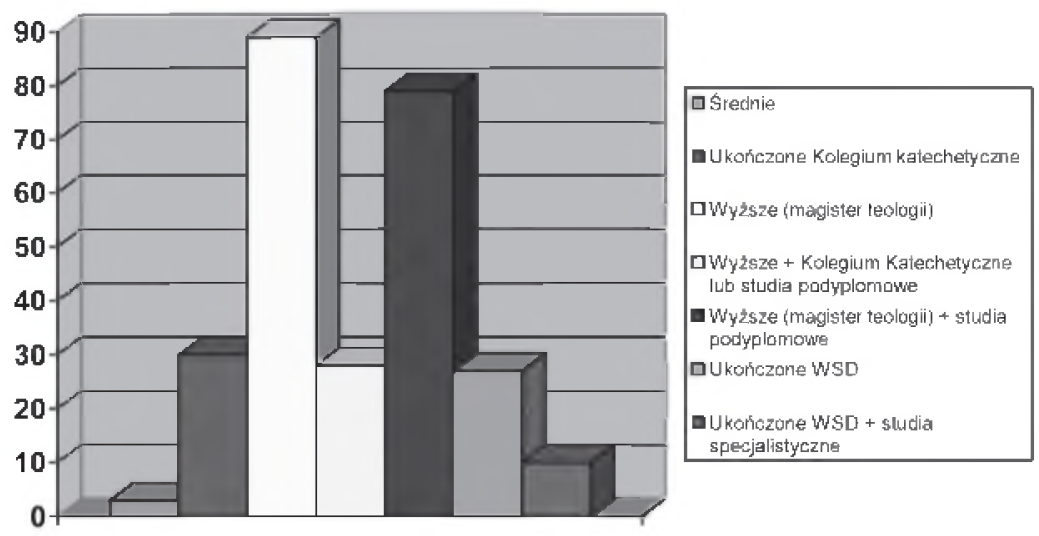

Badani nauczyciele w momencie badań pracowali w: szkołach podstawowych (klasy 1-2) - 60,90\%, szkołach podstawowych (klasy 4-6) - 59,90\%, przedszkolach $-36,84 \%$, gimnazjach - 28,57 \%, technikach - 11,65\%, liceach profilowanych - 10,90\%, liceach ogólnokształcących - 7,14\% i zasadniczych szkołach zawodowych - 5,64\%. Zmienna ta wskazuję, że gro nauczycieli uczy w kilku szkołach i na różnych poziomach nauczania. 
Aktywność zawodowa

\begin{tabular}{|l|c|c|}
\hline \multicolumn{1}{|c|}{ Obecnie uczę w: } & \multicolumn{2}{c|}{$\begin{array}{c}\text { Aktywność zawodowa } \\
\text { (N = 266) }\end{array}$} \\
\hline Przedszkolu & 98 & $36,84 \%$ \\
\hline Szkole podstawowej (klasy 1- 3) & 162 & $60,90 \%$ \\
\hline Szkole podstawowej (klasy 4-6) & 157 & $59,90 \%$ \\
\hline Gimnazjum & 76 & $28,57 \%$ \\
\hline Zasadniczej szkole zawodowej & 15 & $5,64 \%$ \\
\hline Technikum & 31 & $11,65 \%$ \\
\hline Liceum profilowanym & 29 & $10,90 \%$ \\
\hline Liceum ogólnokształcącym & 19 & $7,14 \%$ \\
\hline
\end{tabular}

Obecnie uczę w:

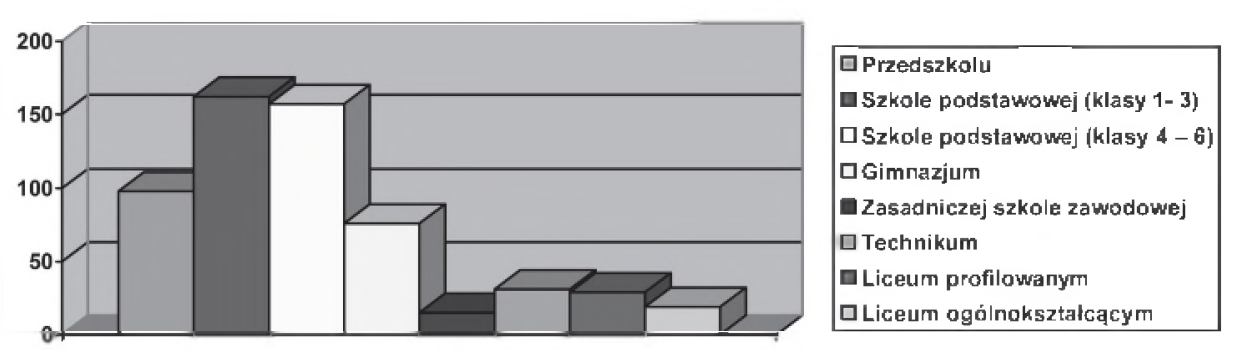

Duża fluktuacja kadr w Kościele w Polsce (częsta przenoszenie księży i sióstr zakonnych na inne placówki) świadczy o tym, że ankietowani mają doświadczenie zawodowe pracując $w$ wielu szkołach na różnych poziomach nauczania. W badanej grupie 81,58 \% nauczycieli uczyło w szkole podstawowej (klasy 1-3), $80,04 \%$ w szkole podstawowej (klasy 4-6), 55,64\% w przedszkolu, 36,09\% w gimnazjum, 20,03\% w zasadniczej szkole zawodowej, 17,67 \% w technikum, $16,54 \%$ w liceum ogólnokształcącym, 14,28 \% w liceum profilowanym, 2,63\% w studium policealnym i 1,13\% na wyższej uczelni.

Tab. 6. Doświadczenie zawodowe

\begin{tabular}{|l|c|c|}
\hline \multicolumn{1}{|c|}{$\begin{array}{c}\text { W swojej karierze nauczycielskiej } \\
\text { pracowałem: }\end{array}$} & \multicolumn{2}{c|}{$\begin{array}{c}\text { Doświadczenie zawodowe } \\
\text { (N= 266) }\end{array}$} \\
\hline w przedszkolu & 148 & $55,64 \%$ \\
\hline w szkole podstawowej (klasy 1 - 3) & 217 & $81,58 \%$ \\
\hline w szkole podstawowej (klasy 4 - 6) & 214 & $80,04 \%$ \\
\hline w gimnazjum & 96 & $36,09 \%$ \\
\hline
\end{tabular}




\begin{tabular}{|l|l|l|}
\hline \multicolumn{1}{|c|}{$\begin{array}{c}\text { W swojej karierze nauczycielskiej } \\
\text { pracowałem: }\end{array}$} & \multicolumn{2}{c|}{$\begin{array}{c}\text { Doświadczenie zawodowe } \\
\text { (N = 266) }\end{array}$} \\
\hline w zasadniczej szkole zawodowej & 54 & $20,03 \%$ \\
\hline w technikum & 47 & $17,67 \%$ \\
\hline w liceum profilowanym & 38 & $14,28 \%$ \\
\hline w liceum ogólnokształcącym & 44 & $16,54 \%$ \\
\hline w studium policealnym & 7 & $2,63 \%$ \\
\hline na uczelni wyższej & 3 & $1,13 \%$ \\
\hline
\end{tabular}

W swojej karierze nauczycielskiej pracowałem:

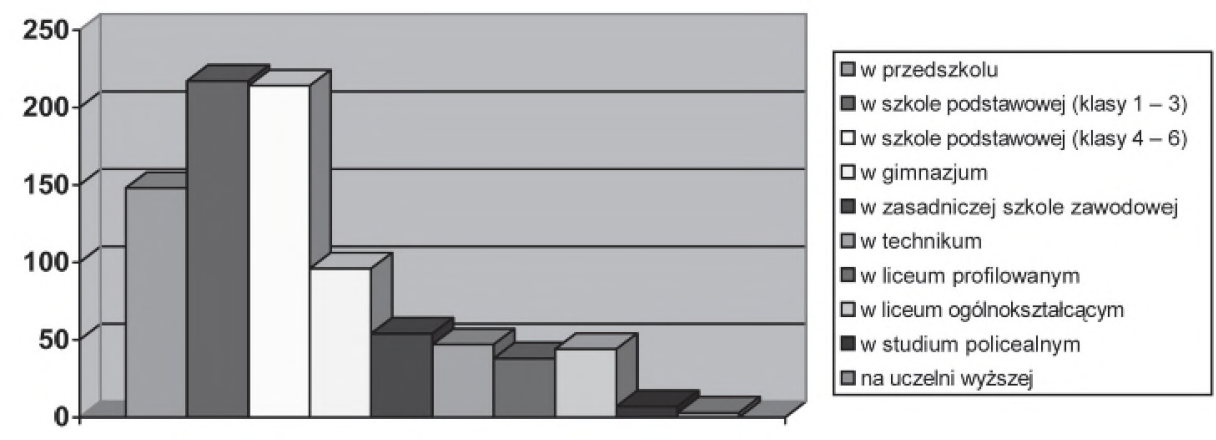

\section{Stan wiedzy i poglądy katechetów}

\section{1. Źródła informacji o środowisku}

W pytaniu dotyczącym źródeł informacji o środowisku dano osobom badanym dziesięć możliwość. Dziewięć określonych i jedną otwartą, ponadto było to pytanie wielokrotnego wyboru.

Analiza wyników przeprowadzonych wśród nauczycieli religii w diecezji łomżyńskiej ujawniła, ze głównym źródłem informacji o środowisku jest telewizja $(64,3 \%)$. Kolejnymi ważnymi źródłami, są prasa $(46,1 \%)$ i rozmowy z ludźmi (45,7\%). Następną grupę źródeł stanowią: lektury książek ( $24,5 \%$ ), audycje radiowe $(19,7 \%)$ oraz elektroniczne techniki informacyjne $(18,6 \%)$. Dalszą grupę stanowią: szkolenia zawodowe $(11,5 \%)$ i plakaty i obwieszczenia $(10,4 \%)$. Najsłabszym źródłem informacji o środowisku w badanej grupie okazały się wystawy ekologiczne (4,8\%). Ankietowani ponadto podali własne obserwacje środowiska $(4,1 \%)$, studia podyplomowe z ochrony przyrody $(0,7 \%)$, edukacja ekologiczna na studiach i wycieczki po $(0,4 \%)$. 
Źródta informacji o środowisku

\begin{tabular}{|c|c|c|c|}
\hline \multicolumn{4}{|c|}{ Źródła informacji } \\
\hline \multicolumn{2}{|c|}{ telewizja } & 173 & $64,3 \%$ \\
\hline \multicolumn{2}{|c|}{ prasa } & 124 & $46,1 \%$ \\
\hline \multicolumn{2}{|c|}{ rozmowy z ludźmi } & 123 & $45,7 \%$ \\
\hline \multicolumn{2}{|c|}{ książki } & 66 & $24,5 \%$ \\
\hline \multicolumn{2}{|c|}{ radio } & 53 & $19,7 \%$ \\
\hline \multicolumn{2}{|c|}{ Internet } & 50 & $18,6 \%$ \\
\hline \multicolumn{2}{|c|}{ szkolenia zawodowe } & 31 & $11,5 \%$ \\
\hline \multicolumn{2}{|c|}{ plakaty i obwieszczenia } & 28 & $10,4 \%$ \\
\hline \multicolumn{2}{|c|}{ wystawy (ekologiczne) } & 13 & $4,8 \%$ \\
\hline \multirow{4}{*}{ inne } & $\begin{array}{l}\text { obserwacje środowiska (obserwacje } \\
\text { własne) }\end{array}$ & 11 & $4,1 \%$ \\
\hline & studia podyplomowe $\mathrm{z}$ ochrony przyrody & 2 & $0,7 \%$ \\
\hline & edukacja ekologiczna na studiach & 1 & $0,4 \%$ \\
\hline & wycieczki & 1 & $0,4 \%$ \\
\hline
\end{tabular}

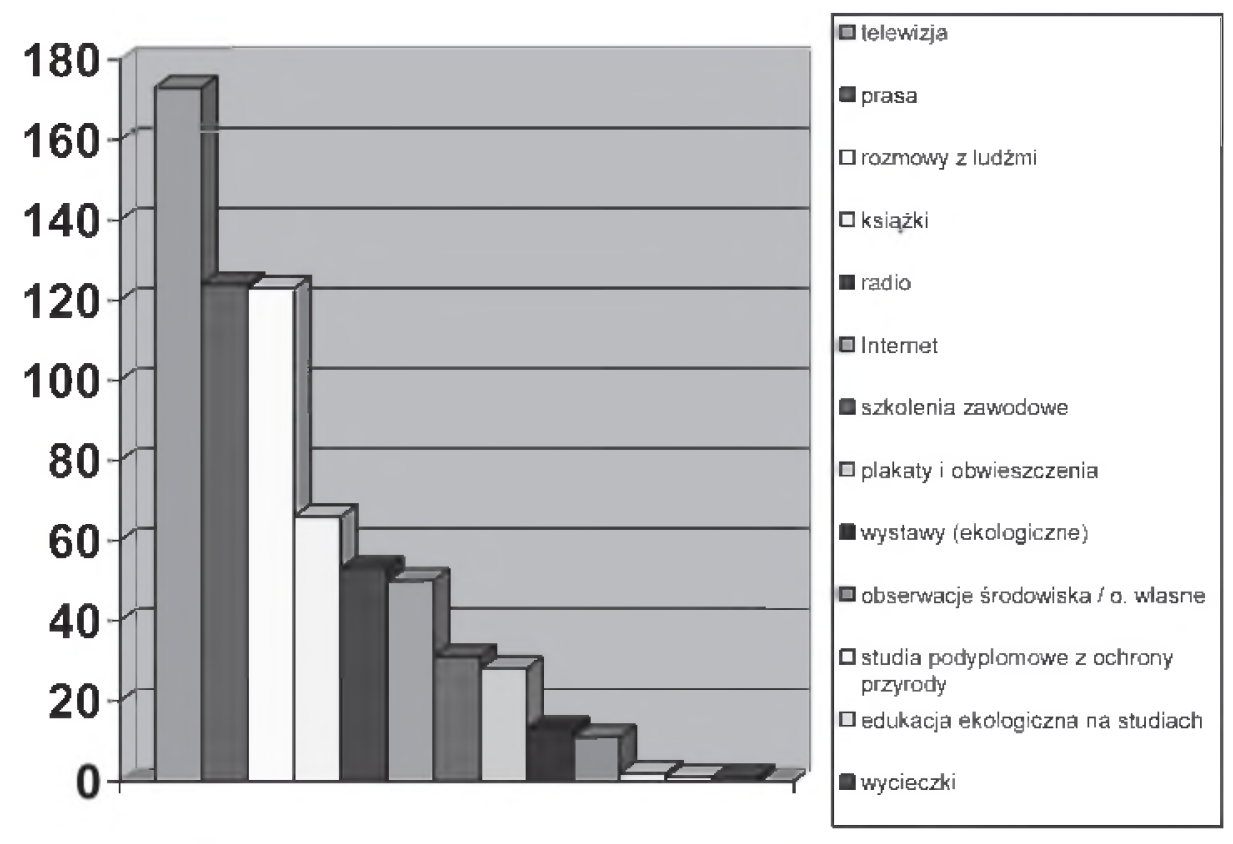


Na pytanie dotyczące czasopism o tematyce proekologicznej jedynie 45,6 \% podało pozytywną odpowiedź, $45,5 \%$ podało odpowiedź negatywną, a $8,7 \%$ nie odpowiedziało na to pytanie.

\begin{tabular}{|l|c|c|}
\hline \multicolumn{3}{|c|}{ Czy zna Pan/Pani czasopisma o tematyce „proekologicznej”? } \\
\hline tak & 122 & $45,6 \%$ \\
\hline nie & 121 & $45,5 \%$ \\
\hline <brak danych> & 23 & $8,7 \%$ \\
\hline
\end{tabular}

Wśród wymienianych tytułów czasopism najczęściej wymieniane, to: Ekoświat (17,8\%), Aura (10,4\%), Przyroda Polska (7,8 \%), Poznaj Świat (3,7\%), Echa Leśne (3,0 \%), Poznaj Swój Kraj (3,0 \%). Na uwagę zasługuje tu fakt podawania tytułów czasopism, które nigdy nie istniało lub podawanie niepełnej nazwy np. Ekologia (4,5\%).

\begin{tabular}{|l|c|c|}
\hline \multicolumn{3}{|c|}{ Tytuły najczęściej wskazanych czasopism „proekologicznych” } \\
\hline Ekoświat & 48 & $17,8 \%$ \\
\hline Aura & 28 & $10,4 \%$ \\
\hline Przyroda Polska & 21 & $7,8 \%$ \\
\hline Poznaj Ŝwiat & 10 & $3,7 \%$ \\
\hline Echa Leśne & 8 & $3,0 \%$ \\
\hline Poznaj Swój Kraj & 8 & $3,0 \%$ \\
\hline Przyroda & 7 & $2,6 \%$ \\
\hline Parki Narodowe & 5 & $1,9 \%$ \\
\hline Biuletyn Polskiego Klubu Ekologicznego & 4 & $1,5 \%$ \\
\hline National Geografic & 4 & $1,5 \%$ \\
\hline Eko Styl & 3 & $1,1 \%$ \\
\hline Zwierzaki & 3 & $1,1 \%$ \\
\hline Raj & 3 & $1,1 \%$ \\
\hline Gaja & 3 & $1,1 \%$ \\
\hline Ziemia Rodzinna & 3 & $1,1 \%$ \\
\hline Wiedza i Życie & 3 & $1,1 \%$ \\
\hline
\end{tabular}


Tytuty najczessiciej wskazanych czasopism „proekologicznych"

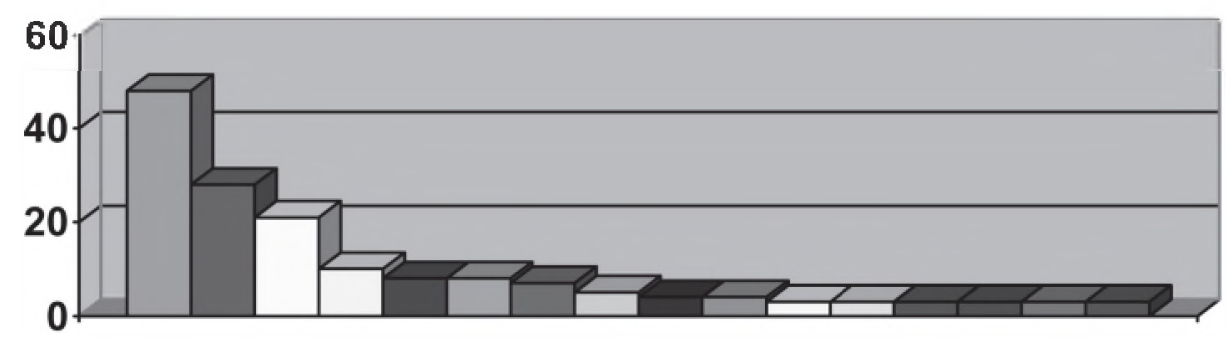

\begin{tabular}{|c|c|}
\hline 口Ekoswiat & 口Aura \\
\hline 口Przyroda Polska & 口 Poznaj Swiat \\
\hline Echa Leśne & 口Poznaj swój kraj \\
\hline Drzyroda & 口Parki Narodowe \\
\hline Diuletyn Polskiego Klubu Ekologicznego & $\square$ National Geografic \\
\hline 口Eko Styl & ㄱwierzaki \\
\hline QRaj & Q Gaja \\
\hline 口Ziemia Rodzinna & D Wiedza i Žycle \\
\hline
\end{tabular}

\subsection{Opinie i poglądy na temat wybranych problemów środowiskowych}

Kolejne pytania ankiety dobrano w celu poznania opinii i poglądów ochrony i kształtowania środowiska. Pierwsze pytanie z tej grupy dotyczy najskuteczniejszych form ochrony przyrody. Badani w przytłaczającej większości wskazali na edukację ekologiczną (91,4 \%), w następnej kolejności wskazano na stosowanie surowych kar $(64,7 \%)$, a dalej na dobrze rozwiniętą technikę pozwalającą na usunięcie skutków kryzysów ekologicznych (26,8\%). Za najmniej skuteczny sposób uznano strajki ekologiczne (2,6\%). Respondenci podali też własne rozwiązania, głównie dotyczące dobrego i skutecznego prawa dotyczącego ochrony przyrody oraz poprawę stanu materialnego społeczeństwa po to, by posiadało środki finansowe na ochronę środowiska.

\begin{tabular}{|l|r|c|}
\hline \multicolumn{3}{|c|}{ Najskuteczniejsze formy ochrony przyrody } \\
\hline edukacja ekologiczna społeczeństwa & 246 & $91,4 \%$ \\
\hline stosowanie surowych kar & 174 & $64,7 \%$ \\
\hline $\begin{array}{l}\text { dobrze rozwinięta technika pozwalająca na usunię- } \\
\text { cie skutków kryzysów ekologicznych }\end{array}$ & 72 & $26,8 \%$ \\
\hline strajki ekologiczne & 7 & $2,6 \%$ \\
\hline inne & 23 & $9,2 \%$ \\
\hline <brak danych> & 5 & $1,9 \%$ \\
\hline
\end{tabular}


Najskuteczniejsze formy ochrony przyrody

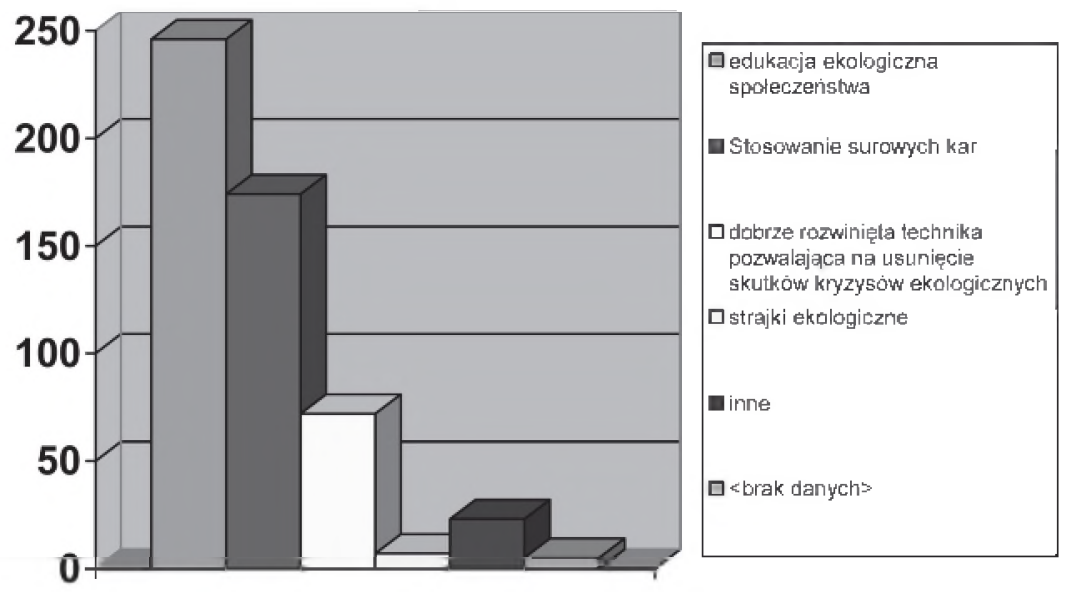

Na pytanie dotyczące relacji pomiędzy polityką ekologiczno-ekonomiczną państwa zdecydowana większość (92,1\%) odpowiedziało, że bez względu na wprowadzane reformy część pieniędzy musi być przekazana na ochronę środowiska. O tym, że w obecnej sytuacji ekonomicznej Polski pieniądze z budżetu lepiej przeznaczyć na rozpoczęte reformy niż na ochronę środowiska uważało $3,4 \%$, a 2,2 \% uważało, że Polski nie stać, aby w obecnej sytuacji ekonomicznej zajmować się problemami ochrony środowiska. Ponadto $2,2 \%$ wyraziło wątpliwości, niedoceniając powiązania troski o środowisko z ochroną życia i zdrowia człowieka - mówiąc -, że ochrona środowiska jest ważna, ale równie ważni są ludzie. Wypowiedzi te są dyktowane widokiem ubóstwa na co dzień. Zwłaszcza wśród uczniów.

\begin{tabular}{|l|c|c|}
\hline \multicolumn{3}{|c|}{ Ochrona i ksztaltowanie środowiska a polityka państwa } \\
\hline $\begin{array}{l}\text { Bez względu na wprowadzane reformy część pienię- } \\
\text { dzy musi być przekazana na ochronę środowiska }\end{array}$ & 245 & $92,1 \%$ \\
\hline $\begin{array}{l}\text { W obecnej sytuacji ekonomicznej Polski pieniądze } \\
\text { zbudżetu lepiej przeznaczyć na rozpoczęte reformy } \\
\text { niż na ochronę środowiska }\end{array}$ & 9 & $3,4 \%$ \\
\hline $\begin{array}{l}\text { Polski nie stać, aby w obecnej sytuacji ekonomicz- } \\
\text { nej zajmować się problemami ochrony środowiska }\end{array}$ & 6 & $2,2 \%$ \\
\hline Trudno powiedzieć & 6 & $2,2 \%$ \\
\hline
\end{tabular}


Ochrona i ksztaltowanie środowiska a polityka państwa
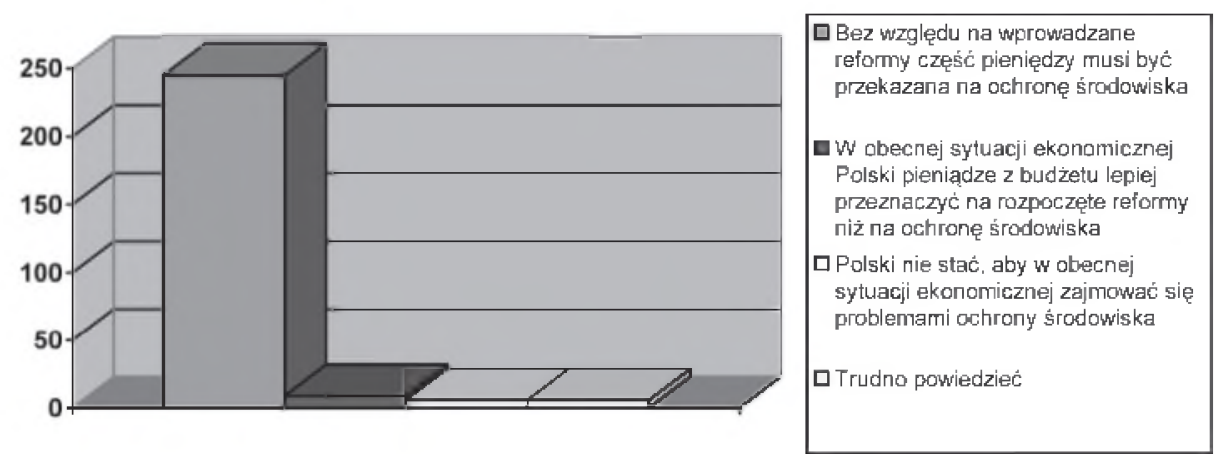

Na pytanie dotyczące miejsca edukacji ekologicznej w systemie oświaty gro nauczycieli rozumie potrzebę tego rodzaju edukacji od przedszkola $(91,1 \%)$ poprzez szkołę podstawową (95,2 \%), gimnazjum (94,8 \%) do szkoły średniej (90,3 \%). Potrzebę edukacji ekologicznej dorosłych widzi $(80,3 \%)$ w szkołach wyższych i $(75,5 \%)$ wśród dorosłych, którzy ukończyli kształcenie.

\begin{tabular}{|l|c|c|}
\hline \multicolumn{3}{|c|}{ Miejsce edukacji środowiskowej w polskim systemie oświaty } \\
\hline szkole podstawowej & 256 & $95,2 \%$ \\
\hline gimnazjum & 255 & $94,8 \%$ \\
\hline przedszkole & 245 & $91,1 \%$ \\
\hline szkołach średnich & 243 & $90,3 \%$ \\
\hline na studiach wyższych & 216 & $80,3 \%$ \\
\hline wśród dorosłych, którzy ukończyli kształcenie & 203 & $75,5 \%$ \\
\hline <brak danych> & 1 & $0,4 \%$ \\
\hline
\end{tabular}

Miejsce edukacji środowiskowej w polskim systemie oświaty

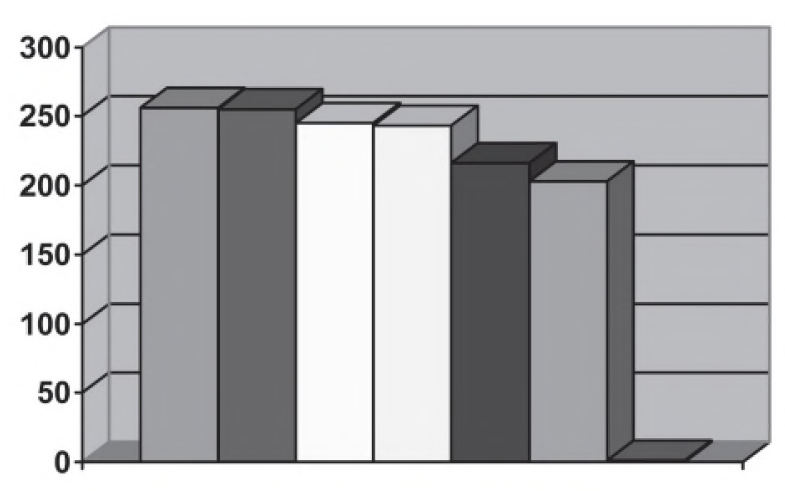

\begin{tabular}{|l|}
\hline szkole podstawowej \\
$\square$ gimnazjum \\
$\square$ przedszkole \\
$\square$ szkołach średnich \\
$\square$ na studiach wyższych \\
$\square$ wśród dorosłych, którzy ukończyli \\
kształcenie \\
$\square<$ brak danych> \\
\hline
\end{tabular}




\subsection{Wiedza ogólna na temat ochrony i kształtowania środowiska}

Dwa następne pytania przygotowano w celu sprawdzenia wiedzy ogólnej respondentów na temat ochrony i kształtowania środowiska. Były to pytania otwarte. Na pierwsze $\mathrm{z}$ nich jedynie $27,8 \%$ odpowiedzi było prawidłowych, 7,1 $\%$ respondentów nie udzieliło odpowiedzi, a $65,1 \%$ odpowiedzi było nieprawidłowych było nieprawidłowych.

Najwięcej odpowiedzi prawidłowych jest w grupie nauczycieli mających wykształcenie wyższe nieteologiczne plus ukończone kolegium katechetyczne lub studia podyplomowe. Natomiast księża najlepiej wykształceni (Wyższe Seminarium Duchowne plus studia specjalistyczne) nie udzielili ani jednej prawidłowej odpowiedzi. Natomiast wśród grup wiekowych najmniej prawidłowych odpowiedzi udzielili nauczyciele młodzi (26 - 30 lat) i najstarsi (51 - 65 lat). Stąd można wysunąć wniosek, że poziom wykształcenia teologicznego i wiek respondentów nie ma większego znaczenia w badaniach wiedzy ekologicznej.

\begin{tabular}{|l|l|c|}
\hline \multicolumn{2}{|c|}{ Zmienne niezależne } & $\begin{array}{c}\text { Odpowiedzi prawidłowe } \\
\text { (wskaźnik \%) }\end{array}$ \\
\hline \multirow{5}{*}{ Płeć } & Kobiety & 27,6 \\
\cline { 2 - 3 } & Mężczyźni & 28,6 \\
\cline { 2 - 3 } & <brak danych> & 14,3 \\
\hline \multirow{5}{*}{ Wiek } & Do 25 lat & 40,0 \\
\cline { 2 - 3 } & $26-30$ lat & 17,2 \\
\cline { 2 - 3 } & $31-40$ lat & 30,7 \\
\cline { 2 - 3 } & $41-50$ lat & 30,4 \\
\cline { 2 - 3 } & $51-65$ lat & 17,6 \\
\hline \multirow{5}{*}{ wykształcenie } & $\begin{array}{l}\text { Wyższe Seminarium Duchowne + } \\
\text { studia specjalistyczne }\end{array}$ & 0 \\
\cline { 2 - 3 } & Wyższe Seminarium Duchowne & 34,5 \\
\cline { 2 - 3 } & $\begin{array}{l}\text { Wyższe teologiczne (magister teologii) } \\
\text { + studia podyplomowe }\end{array}$ & 31,6 \\
\cline { 2 - 3 } & $\begin{array}{l}\text { Wyższe + kolegium katechetyczne lub } \\
\text { studia podyplomowe }\end{array}$ & 39,3 \\
\cline { 2 - 3 } & Wyższe teologiczne (magister teologii) & 23,1 \\
\cline { 2 - 3 } & Kolegium katechetyczne & 30,0 \\
\cline { 2 - 3 } & Ślednie & 33,3 \\
\hline
\end{tabular}


Płeć (wskaźnik \%)

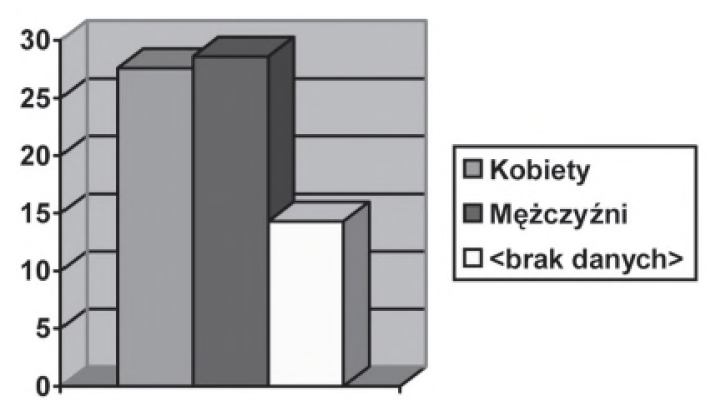

Wiek (wskaźnik\%)

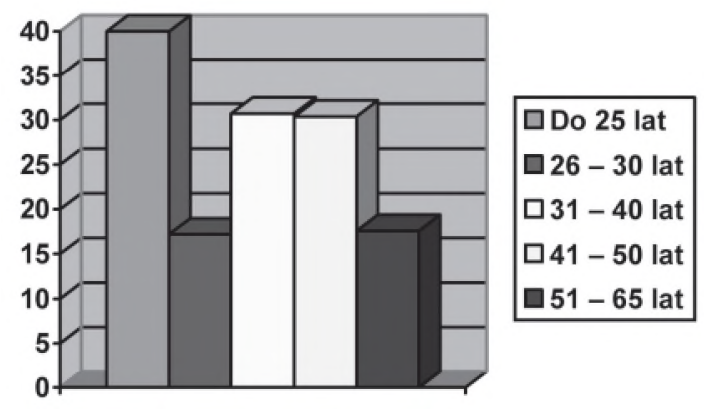

Wyksztakcenie (wskaźnik\%)

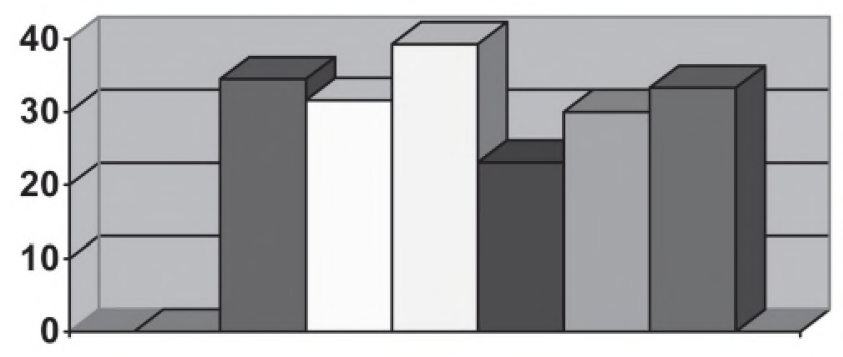

\begin{tabular}{|l|}
\hline Wyższe Seminarium Duchowne + studia specjalistyczne \\
$\square$ Wyższe Seminarium Duchowne \\
$\square$ Wyższe teologiczne (magister teologii) + studia podyplomowe \\
$\square$ Wyższe + kolegium katechetyczne lub studia podyplomowe \\
$\square$ Wyższe teologiczne (magister teologii) \\
$\square$ Kolegium katechetyczne \\
$\square$ Średnie
\end{tabular}

Na pytanie drugie, które było pytaniem otwartym wszyscy respondenci udzielili po pięć prawidłowych odpowiedzi. 


\subsection{Nastawienia „prośrodowiskowe" badanych - oceny, przekonania, deklarowane zachowania}

Analiza wyników odpowiedzi na 24 pytania dotyczące nastawienia „prośrodowiskowego" badanych nauczycieli religii ze względu na płeć, wiek i wykształcenie pozwoliła ustalić, że grupa kobiet uzyskała statystycznie wyższe wyniki, można więc przypuszczać, iż kobiety są bardziej "prośrodowiskowo" nastawione do problematyki ochrony i kształtowania środowiska niż mężczyźni.

Analiza uwzględniająca wiek badanych wykazała, że najbardziej nastawieni "prośrodowiskowo" są początkujący nauczyciele należący do grupy wiekowej do 25 lat i najstarsi mający po 51 i więcej lat. Natomiast najmniej zainteresowane należały do grupy wiekowej 26 - 30 lat.

Pod względem wykształcenia najgorsze wynik mieli księża, zwłaszcza ci, którzy są najlepiej wykształceni mający skończone dodatkowe studia specjalistyczne oraz katecheci świeccy i siostry zakonne mający ukończone jedynie magisterskie studia teologiczne. Natomiast najbardziej nastawieni "prośrodowiskowo" są magistrowie teologii, którzy uzupełnili wykształcenie na studiach podyplomowych oraz nauczyciele posiadający wykształcenie wyższe nieteologiczne, którzy uzyskali uprawnienia do nauczania religii poprzez ukończenie kolegium katechetycznego lub studia podyplomowe. Niezły wynik uzyskały osoby, które ukończyły jedynie kolegium katechetyczne.

\begin{tabular}{|c|c|c|c|c|c|}
\hline \multicolumn{2}{|r|}{ Zmienna niezależna } & $\mathbf{N}$ & Średnia & Minimum & Maksimum \\
\hline \multicolumn{2}{|r|}{ Ogól } & 266 & 66,70 & 19,0 & 95,6 \\
\hline \multirow{2}{*}{ Płeć } & Kobiety & 192 & 68,24 & 21,3 & 95,8 \\
\hline & Mężczyźni & 70 & 61,19 & 12,8 & 95,7 \\
\hline \multirow{5}{*}{ Wiek } & Do 25 lat & 5 & 75,00 & 20,0 & 100,0 \\
\hline & $26-30$ lat & 29 & 65,07 & 6,9 & 93,1 \\
\hline & $31-40$ lat & 137 & 68,73 & 19,0 & 97,8 \\
\hline & $41-50$ lat & 69 & 68,45 & 20,1 & 97,1 \\
\hline & $51-65$ lat & 17 & 69,19 & 23,5 & 100,0 \\
\hline \multirow{7}{*}{$\begin{array}{l}\text { Wykształ- } \\
\text { cenie }\end{array}$} & $\begin{array}{l}\text { Ukończone WSD + studia } \\
\text { specjalistyczne }\end{array}$ & 10 & 54,87 & 0 & 90.9 \\
\hline & Ukończone WSD & 27 & 59,75 & 13,8 & 100,0 \\
\hline & $\begin{array}{l}\text { Wyższe (magister teologii) + } \\
\text { studia podyplomowe }\end{array}$ & 79 & 72,63 & 20,1 & 100,0 \\
\hline & $\begin{array}{l}\text { Wyższe + kolegium kateche- } \\
\text { tyczne lub studia podyplomowe }\end{array}$ & 28 & 72,58 & 17,9 & 100,0 \\
\hline & Wyższe (magister teologii) & 89 & 66,57 & 16,6 & 98,1 \\
\hline & Kolegium katechetyczne & 30 & 71,37 & 23,3 & 100,0 \\
\hline & Średnie & 3 & 43,02 & 0 & 100,0 \\
\hline
\end{tabular}




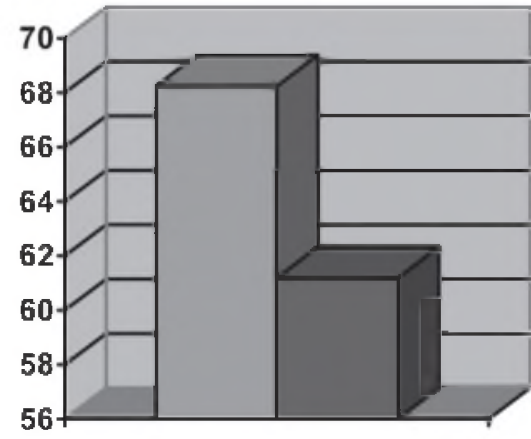

\section{$\square$ Kobiety \\ Mężczyźni}
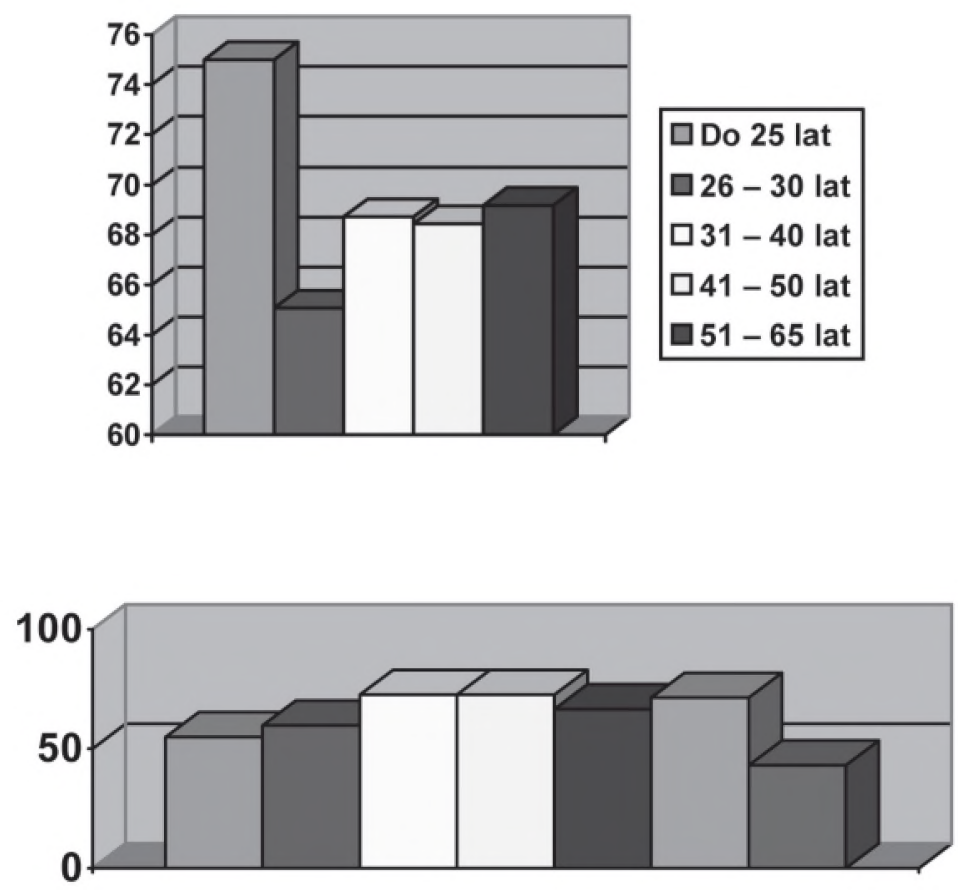

口Ukończone WSD + studia specjalistyczne

口Ukończone WSD

$\square$ Wyższe (magister teologii) + studia podyplomowe

口Wyższe + kolegium katechetyczne lub studia podyplomowe

aWyższe (magister teologii)

$\square$ Kolegium katechetyczne

$\square$ Średnie 
Na pytanie dotyczące samooceny wiedzy z zakresu kształtowania środowiska jedynie $6 \%$ respondentów udzieliła odpowiedzi pozytywnej i pewnej, 49,6 $\%$ odpowiedziało pozytywnie $z$ wahaniem, $12 \%$ nie ma zdania o swej wiedzy, $26,7 \%$ udzieliło odpowiedzi negatywnej i niepewnej, natomiast $4,1 \%$ nie jest zadowolona ze swej wiedzy.

\begin{tabular}{|l|c|c|}
\hline \multicolumn{3}{|c|}{$\begin{array}{c}\text { Uważam, że wiedza którą posiadam jest całkowicie wystarczająca } \\
\text { do podejmowania przeze mnie prawidłowych działań na rzecz ochrony } \\
\text { i kształtowania środowiska }\end{array}$} \\
\hline zdecydowanie tak & 16 & $6,0 \%$ \\
\hline raczej tak & 132 & $49,6 \%$ \\
\hline nie wiem & 32 & $12,0 \%$ \\
\hline raczej nie & 71 & $26,7 \%$ \\
\hline zdecydowanie nie & 11 & $4,1 \%$ \\
\hline$<$ brak danych> & 4 & $1,5 \%$ \\
\hline
\end{tabular}

Uważam, że wiedza którą posiadam jest całkowicie wystarczająca do podejmowania przeze mnie prawidłowych działań na rzecz ochrony i kształtowania środowiska.

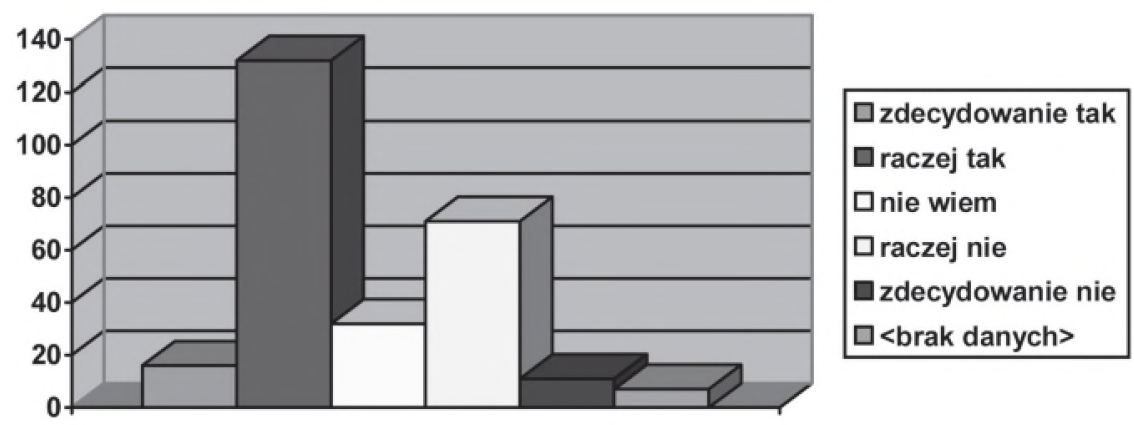

\subsection{Praktyczne wykorzystanie wiedzy ekologicznej}

W celu zbadania umiejętności praktycznego wykorzystania wiedzy ekologicznej postawiono nauczycielom dwa problemy, dotyczące zachowania się nauczyciela-opiekuna młodzieży na biwaku i spływie kajakowym. Pierwsze poruszała sprawę odpadów, drugie zachowania higieny osobistej w miejscach niezindustrializowanych. Na pierwsze pytanie zasugerowano jedną prawidłową odpowiedź, na pytanie drugie zasugerowano dwie prawidłowe odpowiedzi nie podając wiadomości, że pytanie może być wielokrotnego wyboru. Nikt z respondentów nie udzielił dwu odpowiedzi. 
$\mathrm{Z}$ analizy wyników badań wynika, że praktyczne wykorzystanie wiedzy ekologicznej jest lepsze u kobiet niż u mężczyzn. Lepsze wynik uzyskały osoby z większym doświadczeniem życiowym mieszczące się w grupie wiekowej (51 -65 lat) i (40 - 51 lat). Ze względu na wykształcenie najsłabsze wyniki osiągnęli księża, a najlepsze osoby z wykształceniem teologicznym (magistrowie teologii).

\begin{tabular}{|c|c|c|c|c|c|}
\hline \multirow{2}{*}{\multicolumn{2}{|c|}{ Zmienne niezależne }} & \multirow{3}{*}{$\begin{array}{c}\text { Zachowanie } \\
\text { na biwaku } \\
\text { - poprawne } \\
\text { odpowiedzi } \\
(\%) \\
84,0\end{array}$} & \multicolumn{3}{|c|}{$\begin{array}{c}\text { Zachowanie na spływie kajako- } \\
\text { wym - poprawne odpowiedzi } \\
(\%)\end{array}$} \\
\hline & & & Odp. I & Odp. II & Suma \\
\hline \multirow{2}{*}{$\begin{array}{l}1.0 \\
\text { Płeć }\end{array}$} & & & 77,7 & 10,8 & 88,5 \\
\hline & Kobiety & 87.0 & 82,8 & 10,9 & 93,7 \\
\hline \multirow{5}{*}{ Wiek } & Mężczyźni & 77,1 & 62,9 & 11,4 & 74,3 \\
\hline & Do 25 lat & 60.0 & 80,0 & 0 & 80,0 \\
\hline & $26-30$ lat & 82,8 & 69,0 & 10,3 & 79,3 \\
\hline & $30-40$ lat & 83,9 & 74,5 & 12,4 & 86,9 \\
\hline & $41-50$ lat & 87,0 & 82,6 & 10,1 & 92,7 \\
\hline \multirow{8}{*}{$\begin{array}{l}\text { Wykształ- } \\
\text { cenie }\end{array}$} & $51-65$ lat & 88,2 & 88,2 & 11,8 & 100,0 \\
\hline & $\begin{array}{l}\text { Ukończone WSD + } \\
\text { studia specjalistyczne }\end{array}$ & 90,9 & 54,5 & 9,1 & 63,6 \\
\hline & Ukończone WSD & 79,3 & 55,2 & 10,3 & 65,5 \\
\hline & $\begin{array}{l}\text { Wyższe (magister } \\
\text { teologii) + studia } \\
\text { podyplomowe }\end{array}$ & 78,5 & 77,2 & 12,7 & 89,9 \\
\hline & $\begin{array}{l}\text { Wyższe + kolegium } \\
\text { katechetyczne lub stu- } \\
\text { dia podyplomowe }\end{array}$ & 85,7 & 78,6 & 3,6 & 82,2 \\
\hline & $\begin{array}{l}\text { Wyższe (magister } \\
\text { teologii) }\end{array}$ & 88,9 & 78,7 & 10,2 & 88,9 \\
\hline & $\begin{array}{l}\text { Kolegium kateche- } \\
\text { tyczne }\end{array}$ & 96,7 & 70,0 & 13,3 & 83,3 \\
\hline & Srednie & 100.0 & 66,7 & 0 & 66,7 \\
\hline
\end{tabular}

\section{Wnioski}

Badania na temat wiedzy i poglądów nauczycieli religii w zakresie ochrony i kształtowania środowiska naturalnego przeprowadzono metodą kwestionariusza ankietowego wśród katechetów diecezji łomżyńskiej na grupie 266 osób co stanowi $35 \%$ ogółu nauczycieli religii pracujących na danym terenie. 
W badaniach uwzględniono zmienne niezależne:

- płeć

- wiek

- wykształcenie

- staż pracy

- statut zawodowy

- aktywność zawodowa

- doświadczenie zawodowe

Stan wiedzy i poglądy nauczycieli przebadano od strony:

- źródeł informacji o środowisku, gdzie wykazano, że głównymi źródłami jest: telewizja, prasa i rozmowy z ludźmi, co stanowi novum w porównaniu z innymi badaniem przeprowadzanymi w innych środowiskach. ${ }^{2}$

- opinii i poglądów na temat wybranych problemów środowiskowych. Wykazano tutaj, ze ogromną rolę ma na tym polu do spełnienia edukacja ekologiczna prowadzona na wszystkich poziomach nauczania, od przedszkola poprzez szkoły wszystkich typów do ustawicznego kształcenia dorosłych.

- wiedzy ogólnej na temat ochrony i kształtowania środowiska. Wiedza nauczycieli na temat ochrony środowiska okazała się ogólnie dostateczna, choć w niektórych grupach wykształcenia zauważyć można ogromne zaniedbania.

- nastawień "prośrodowiskowych" badanych - oceny, przekonania, deklarowane zachowania. Analiza wykazała, że grupa kobiet uzyskała statystycznie lepsze wyniki niż grupa mężczyzn. Ogólnie oceniono nastawianie "prośrodowiskowe" badanej grupy na stopień dobry z plusem.

- praktycznych wykorzystanie wiedzy ekologicznej. Wyniki badań można ocenić bardzo dobrze i dobrze w zależności od grupy badanych. Zauważono prawidłowość: najlepsze wyniki uzyskali badani, którzy zaliczeni zostali do grup wiekowych (51 - 65 lat) i (41 - 50 lat), natomiast wyraźnie słabsze wyniki uzyskali badani zaliczani do grup (do 25 lat) i (25 - 30 lat).

Podsumowując należy podkreślić, że w badana grupa wykazała się niewystarczającą wiedzą z zakresu ochrony środowiska, mimo iź nastawienie "proekologiczne" oceniono wysoko. Płynie stąd wniosek, że kształceniu ustawicznym nauczycieli należy uwzględnić potrzebę uzupełnienia wiedzy z zakresu sozologii. 


\section{The knowledge and ideas of religion teachers concerning themes about the protection and shaping of the natural environment}

\section{SUMMARY}

The article contains an analysis of the investigation about the knowledge and ideas of religion teachers as regards the protection and the shaping of the natural environment and presents the primary problems of the questionnaire. This was carried out in the Diocese of Lomza with a group of 260 people.

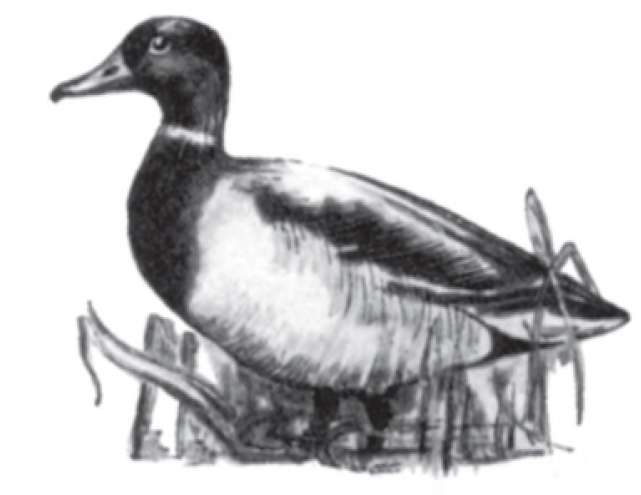

Krzyžówka 